\title{
Determining sources of income among paddy farmers in Muda irrigation area, Malaysia
}

\author{
Ahmad Zubir Ibrahim ${ }^{1}$, Chamhuri Siwar ${ }^{2}$, Basri Abdul Talib ${ }^{3}$ \\ ${ }^{1}$ (School of Government, Universiti Utara Malaysia, Malaysia) \\ ${ }^{2}$ (Institute for Environment and Development, Universiti Kebangsaan Malaysia) \\ 3 (Faculty of Economics and Management, Universiti Kebangsaan Malaysia)
}

\begin{abstract}
This paper aims to determine the determinants of income among paddy farmers in four regions of Muda irrigation areas. For this purpose a total of 225 paddy farmers in Muda irrigation areas were randomly selected. The result of the study showed that the agricultural income accounted for $73.6 \%$ of the total income paddy farmers in Muda irrigation area. While side income accounted for 9.23\%, non-agricultural income accounted for $12.47 \%$ and other income accounted for $4.45 \%$ of the total income of the paddy farmers in this area. Through the double log regression analysis, the study shows that the ownership of lands, land rent, nonagricultural income, subsidy recipients, education level, and number of part time job of household members have a significant result which is a positive relationship towards the income of paddy farmers in this area. To enhance the income, farmers are exposed to rice industry chain value through rice by-products of straw. At the same time, income enhancement programs for the aimed groups need to be strengthened and exaggerate appropriately.
\end{abstract}

Keywords: income, paddy farmers, Muda irrigation area

\section{Introduction}

In accordance with the rice sufficiency policy, the Malaysia government launched several massive agricultural projects under the First Malaysia Plan (1966 - 1970), the largest among them being the Muda Irrigation Scheme. Under the Muda Irrigation Scheme, a drainage and irrigation system was prepared for the coastal plain of Western Kedah and Perlis to enable the planting of two crops of rice per year. The main objective of Muda Irrigation Project is to raise the productivity and incomes of about 16,000 smallholder paddy farming families through improved water management in those parts of the Muda irrigation area which are least adequately served by the existing irrigation and drainage network. In addition, by strengthening agricultural support services, the yield and incomes of all 60,000 paddy farming families in the Muda area, or 340,000 people, will be improved.

Paddy farmers in Muda irrigation area rely mostly on agriculture as the main source of income for their livelihoods which is dominated by rice production. In addition to rice income, small scale livestock raising, vegetable production and non-farming activities serve as additional source of farming household income. The fact that rural household income mostly generates from farming activities increasing households income by focusing on rice cultivation and other income generation activities remains an important issue to all stakeholders. One of many ways to improve households income is to be aware of the characteristic of the rural households and constrains in order to seek the best possible solutions (Marong, 2007). DEFRA (2011) to describe principal farmers' households income has following components; (i). the share of farm business income (including income from farm diversification) attributable to the principal farmer and their spouse, (ii). Principal farmers and spouse's off farm income from employment and self-employment, investment income, pensions and social payment and non farming income of other households members. In this study, we describe the income activities of paddy farmers and examine the determinants of non-farm diversification. Determinants of household income in Muda integration area were clarified by using linear regression analysis.

\section{Litreture Review}

In dealing with the farmers' source of income in the rural areas, many studies have highlighted the importance of non-agricultural activities and income as a contributor to the total income of a household Ho (1979), Adam (1993), Hamza (2007), Roslan and Hadijah(2011). Simultaneously, another source of income received by the farmers are such as remittance from children, income attained according to level of education and rental received according to the size of land actually determines the total income of non-agriculture. Ho, (1979) and Adam (1993; 2001) discussed about the non-farming income activities in reducing poverty and income inequality among the poor. At the same time Hamza (2007), also explained that the contribution of nonagricultural employment have led to the reduction of income inequalities. However, non-farming income and 
employment income is not found to have a significant effect in reducing the severity of poverty compared with the poverty rate. This is because a lot of non-agricultural income possibilities are owned by the farmers in the group approaching the poverty line income (Roslan and Hadijah, 2011).

In most of developing countries, the non-agricultural activities accounted for $50 \%$ of the jobs for the rural population and household income (Lanjouw, 1999). The average non-farming income accounted for $40 \% \mathrm{t}$ of the population in Latin America, 42\% in Africa and 32\% in Asia (World Bank, 2000). The study found that nonfarming income accounts for more than $40 \%$ of lower income in rural areas in Pakistan (Adam, 1993). Hamza, (2007) clarifies that the non-agricultural sector contributed an average of $50 \%$ of household income in Syria, while agricultural income accounted for $30 \%$.

Simultaneously, the duration of the level of education obtained by the heads of households also has an impact on household income. Zhu and Luo,(2006) explained in their study that the income inequality and nonagricultural activities in China were found that, a farmer who has received more than six year period of education has a significant relationship and a positive result $\mathrm{p}<0.01$ for non-agricultural income. Hamza,(2007) in his study enunciated that in rural areas as Darkish and Al-Rastan in Syria indicate that a high level of education of household has a positive relationship with non-agricultural income. Aikaeli, (2010) also found that in Tanzania, the educational level of the household head has a positive and significant relationship to household income in rural areas at the level of $\mathrm{p}<0.01 \%$.

Besides that, a research done by Norsida and Sami,(2006) found that the land ownership variable itself also has a positive and significant relationship $\mathrm{p}<0.01$ on the involvement of non-agricultural activities. For farmers who rent land, the study explains that there is a positive and significant relationship at the level of $p$ $<0.1$. Moreover, a study done by Aikaeli,(2010) showed that the land has a positive and significant at $p<0.05 \mathrm{on}$ the income of the rural population in Tanzania. Increased ownership of land by $1 \%$ would increase the per capita income of the rural population in the country by $0.4 \%$.

In order to ensure a better life, the number of households engaged in non-agricultural activities is important as the agricultural activities because it will contribute to an increase in household income. By using a probit model, Zhu and Luo,(2006) described a positive and significant correlation $\mathrm{p}<0.01$ in the number of households involved in non-agricultural activities of household income in China. Meanwhile, Hamza,(2007) in his study found that the salaries received by other non-agricultural activities (working in public sectors, business and labor contracts) accounted for $57 \%$ of the total income of the rural population in Syria.

To ensure fairness in household income, government assistance through subsidies is seen as a factor that helps the farmers in rural areas in particular to achieve a better life. In other words, the government subsidies seen as vital for enhancing production thereby increasing household income. Roslan and Hadijah (2011) explains that it is troublesome to the paddy farmers in the Muda irrigation area to enhance their income through planting paddy because the majority of farmers are still small-scaled cultivators and need the help of subsidies from the government to pass the poverty line. This statement clarifies that the government subsidies are still needed to help the farmers to enjoy a better standard of living.

\section{Methodology}

This study involved 225 respondents among paddy farmers, who were randomly selected from four main regions of Muda irrigation area. To determine the factors that affect the amount of income of paddy farmers, the double log regression model was developed and assumed as follows:

$$
\ln Y_{2}=\beta_{0}+\beta_{1} \ln X_{1}+\beta_{2} \ln X_{2}+\beta_{3} \ln X_{3}+\beta_{4} \ln X_{4}+\beta_{5} D_{1}+\beta_{6} D_{2}+\beta_{7} D_{3}+\beta_{8} D_{4}+\beta_{9} D_{5}+\beta_{10} D_{6}+\mu_{i}
$$

Where:

$\begin{array}{lll}\mathrm{Y}_{1} & = & \text { income household/month (RM) } \\ \mathrm{X}_{1} & = & \text { own land (hectare) } \\ \mathrm{X}_{2} & = & \text { land rent (hectare) } \\ \mathrm{X}_{3} & = & \text { non-farm income (percent) } \\ \mathrm{X}_{4} & = & \text { other income (percent) } \\ \mathrm{D}_{1} & = & \text { dummy subsidy receipts } \\ \mathrm{D}_{2} & = & \text { dummy level education } \\ \mathrm{D}_{3} & = & \text { dummy health status } \\ \mathrm{D}_{4} & = & \text { dummy saving } \\ \mathrm{D}_{5} & = & \text { dummy sideline } \\ \mathrm{D}_{6} & = & \text { dummy household members working } \\ \mu_{i} & = & \text { random variable } \\ \beta_{1}, \ldots, \beta_{10} & = & \text { correlation coefficient }\end{array}$


Dummy variable also to used in equation. Dummy variable as a non-metrically measured variable transformed into a metric variable by assigning a 1 or a 0 to a subject depending on whether it possesses a particular characteristic (Hair et al. 2006). Dummy variables can be incorporated in regression model just as easily as quantitative model. As a matter of fact a, a regression model may contain regressor that are all exclusively dummy or qualitative in nature (Gujarati, 2003). To measure dummy change from 0 to 1 , the below equation to used (Griffiths,1993).

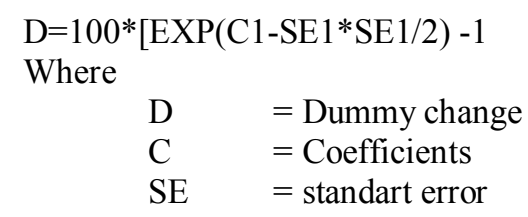

\section{Survey Results}

This study found that the total household income includes rice planting activities besides the wife's income, receiving money from children, welfare assistance from various agencies, pensions, rental properties and other sources of finance. The study also found that the income of paddy farmers in irrigation areas dependent on paddy resources. These crops contribute sources of RM1597.28 (73.85\%) per month of the total income of the respondents. These amounts include paddy price subsidy given by the government an average of RM221.71 (10.25\%) per month. At the same time, the study also identified that non-farming income also contributed to the income of the respondent, but in a small percentage of the total of $12.47 \%$, or an average of RM269.62. Side income received by the farmers (includes rubber plantation, livestock farming and fish nurturing) contributes to the income of paddy farmers average of RM199.62 (23.9\%) of the total income of farmers in this area. Other sources of income such as zakat, remittances from children, and rentals also contribute a percentage of $4.45 \%$ of the total income of paddy farmers (Table1). The study also found an average of monthly income of the respondents is RM2162.70. Most of the respondents in the survey were found to earn around RM1001 to RM2000 per month and a total of 110 respondents or $48.9 \%$ of the farmers placed within this category. In the paddy farmers, 10 people or $4.4 \%$ earned more than RM5000 per month around (Table2).

Referring to Table 3, in the double log model shows that the $\mathrm{R}^{2}$ value is 0.329 and adjusted $\bar{R}^{2}$ value is 0.298. In this study, the model variables $\mathrm{X}_{1}$ (land owner) positively related to the income of paddy farmers. This relationship is significant at the level of $\mathrm{p}<0.01$. This relationship explains that increasing in the area of land belonging to the highest potential income. For the relationship variables $\mathrm{X}_{2}$ (land rent) to the total income, regression analysis showed a positive and significant correlation at the level of $\mathrm{p}<0.1$. This relationship explains that the increase in rent of land ownership among the farmers will increase their income. Flexibility in terms of average rent increase land ownership by farmers of rice per hectare will increase the income of this group of $0.129 \%$ on the assumption of other factors are constant. These variables $\mathrm{X}_{3}$ (non-farm income) showed a positive and significant relationship at the level of $\mathrm{p}<0.1$ for this group. This relationship also clarifies that the total income of paddy farmers is also affected by non-agricultural income includes salaries, wages, and trade. The findings also make it clear that non-agricultural activities either through part time job and other types of work was able to increase the income of this group.

The remittance from children, rental collection, pension, zakat, social services are important to ensure that the farmers to survive. The income was interpreted through the variable $\mathrm{X}_{4}$ (including other source of income). The regression analysis presented that $\mathrm{X}_{4}$, variable has a positive relationship on the income of paddy farmers, but not significant. Recipients of aid or indirect subsidies also help to improve the total income of the farmers. Through the relationship variable $\mathrm{D}_{1}$ (subsidy receipts) with total income regression analysis found a positive and significant relationship exists for paddy farmers at the level $\mathrm{p}<0.01$. Total income for paddy farmers will increase by $24.3 \%$ if they receive subsidies, assuming other factors are constant. This situation also explains the subsidy from the government is needed to ensure that these groups continue to generate their income through the production of paddy plants. Acceptable level of education also plays an important role in generating income. Rationally the higher the level of education obtained higher the amount of the income can be generated. Through relationships of $\mathrm{D}_{2}$ (level of education) with the total income, the study found a positive and significant correlation at the level of $\mathrm{p}<0.1$ for paddy farmers.

Besides that, health status among paddy farmers also contributed to the increase in income. Good health owned by the farmers will enable these people to perform daily activities either working in the fields or doing side jobs for the purpose of improving their living standards. This situation would be otherwise if these group people have health problems. The research shows that the $\mathrm{D}_{3}$ variable (health status) showed a positive relationship on total income of paddy farmers in the Muda irrigation area. However, this relationship does not 
show an insignificant relationship. The income of paddy farmers in the Muda irrigation will increase by $10.6 \%$ if the farmers had no illnesses.

Furthermore, savings among paddy farmers also increase their income through dividends or interest received each year from banks. Based on the analysis of studies conducted, found that there was a positive relationship between the practices of saving on the total income of farmers in the Muda irrigation area. However, this relationship is not significant. Total income of paddy farmers would increase by $0.17 \%$ if the paddy farmers make savings. Part time jobs performed by paddy farmers either jobbing house building, security guards and others will indirectly increase the total income of group. The study conducted found there is a positive and significant correlation at the level of $\mathrm{p}<0.05$ between variables $\mathrm{D}_{4}$ (sideline) with the total income of paddy farmers. Farmers' income will increase by $14.3 \%$ in case of paddy farmers in the Muda irrigation area with the expectation of that other factors are constant.

The last variable used in the regression analysis is variable $\mathrm{D}_{5}$ (household members working public / private sector). Referring to the analysis, this variable has a positive and significant relationship at the level of $p$ $<0.01$ on the total income for this group. The findings of this study make it clear that members of the household who work either public or private sector also contributed to the household income. This study interprets that more and more number of household members, who work, directly will increase total income. Household income will increase by $25.6 \%$ when there are members of the household work, assuming other factors are constant.

\subsection{Impact on household income and poverty}

\section{Discussion}

Income is an important indicator to measure the individual standard or living. In Muda irrigation area, there are four component of sources of farmer income, which consist of agricultural income, side income, nonagricultural income (wages, salary and small business among household farmers) and other income (such as rental, zakat, pensions). Establishment Muda irrigation area, have positive impacts on increasing the overall of farmers in study area. Implementation this project (Muda irrigation area) to reduce poverty level of farmers in this area from $72 \%$ (1966) to $1.4 \%$ in 2008 .

It can concluded that Muda irrigation area were effective in enhancing farmers income. However, from this study, generally paddy farmers in this area not effective in increasing non-agricultural income. They are completely dependent on agricultural income. This study also show that, there are not many people who are involved in these activities (non-agricultural) and statistically does not contribute to change in the level of farmers income in the study.

\subsection{Impact on livelihood strategy}

The higher participating paddy farmer in Muda irrigation area were involve in agricultural activities shows that they have a strong back ground in this field compared to other activities. However, participant of farmers in other activities especially small scale business must be emphasize by government through Farmer Organization Area. This activities very important to implementation because to avoid farmers fall in vulnerability group.

\section{Conclusions}

On average the total income of paddy farmers in the Muda irrigation area is RM2162.70 per month. Based on the research done, the paddy farmers in the area rely heavily on paddy crops as main source of income. The study also found that paddy crops contribute more than $70 \%$ of the total income earned. The percentage of the total paddy price subsidies also contributed $10.25 \%$ to the total income of paddy farmers in the Muda irrigation area. If the government decided to withdraw this subsidy, it will create a number of paddy farmers by $1.8 \%$ classified as extremely poor and $9.3 \%$ are classified as poor.

Non-agricultural income also contributed to the income, but unfortunately it only contributes only around $20 \%$ of the total income earned. The study found that paddy farmers will depend on subsidies to increase the primary income. The findings make it clear that government involvement in ensuring the livelihood of paddy farmers still needed. In addition, the number of household members employed in the public or private sector also contributed to the increase in household income of paddy farmers.

Based on studies conducted, received subsidies, education level and employment side is a major determinant of income in respect of a positive and significant for paddy farmers who earn less than RM1000. The average income for paddy farmers in this category is RM874.18. While for paddy farmers with incomes of more than RM1000, obtained possession of their own land, rent land, non-agricultural income, subsidy receipts and number of household members working in the public and private sectors have a positive and significant relationship of this group of paddy farmers' income with an average income of RM2377.38. 
To increase paddy farmers' incomes, off-farm income should be expanded and enhanced. Rice industry value chain through rice crop by products such as straw should be addressed and promoted. Optimal utilization of straw for this purpose also directly solves the problem in the open burning of rice straw. Straw industry is also seen as an alternative to promote the use of compost to replace chemical-based fertilizers. Recognizing the importance of rice by-products, continuous efforts should be made by the organization to attract and encourage paddy farmers to optimize the use of rice by products. The project is capable of providing a worthwhile return to the paddy farmers undertaking.

At the same time downstream cluster approach should be done. Strength and ability of each group should be evaluated prior to knowing the appropriate areas of activity for the target groups. The implementation of this program should be monitored and continuous injection of motivation to ensure that those involved are constantly working and not give up. The participants are not necessarily made up of the heads of households, but also can include wives, farmers, unemployed youth and school leavers who are interested in attending. At the same time farmer's combination units available under the operation of the Farmers' Organization Area (FOA) is the right move for this undertaking.

Through this combination of expertise of the participants in any of the fields can be obtained to produce a high quality product. No doubt there are some paddy farmers have expertise in certain areas, but as there is no provision of opportunities and constraints has resulted in expertise, not fully utilized. Through the guidance under the FOA handling as the key will encourage paddy farmers to be involved in downstream activities. In addition to social and economic welfare of the members of the FOA, the agency may also conduct marketing activities under the operation of the activity is centered by Muda Agricultural Development Authorities (MADA).

References

[1] Chea Marong, Shoji Shinkai \& Kazuhiko Hotta (2007). A study of factors Affecting Farming Household Income. J.Fac.Agr., Kyushu Univ., 52(1),203-211

[2\} Department for Environmrnt Food and Rural Affairs. 2011. Farm household income and household composition: Results from Farm Business Survey: England 2011/12. https://www.gov.uk/ government/uploads/ system/uploads/ attachment data/file/226607/fbs-householdincome201112-statsnotice-06aug13.pdf [25 August 2013]

[3] Ho, S .1979. Decentralized industrialization and rural development: evidence from Taiwan. Economic Development and Cultural Change 28(1):77-96.

[4] Adam, R.H. 1993. Non-farm income and inequality in rural Pakistan, The Pakistan Development Review. 32:4 Part II (Winter 1993):1187-1198

[5] Hamza, R. 2007. Non Agricultural rural activities preliminary results from selected area of Syria, Working paper No.28, National Agricultural Policy Center (NAPC). March.

[6] Roslan \& Siti Hadijah. 2011. . Non Farm Activities and time to exit poverty: A Case study in Kedah, Malaysia. World Review of Business Research Vol 1 (2), May

[7] Lanjouw. 1999. The rural non-farm sector : A note on Policy Options, Non Farm workshop background paper, World Bank

[8] World Bank.2000. Can Africa claim the twenty-First Century. Washington D.C.

[9] Adam, R.H. 2001. Nonfarm income, inequality and poverty in rural Egypt and Jordan. Policy Research Working paper 2571. http://www-wds.worldbank.org /external/ default/ WDS Content Server/ IW3P/IB 2001 /04/13/000094946_01040505331568/ additional/ 129529323 20041118130639.pdf [12 March 2011].

[10] Zhu, N. \& Luo, X. 2006. Nonfarm activity and rural income inequality: A case study of two provinces in China, World Bank Policy Research Working Paper 3811, January.

[11] Aikaeli, J. 2010. Determinants of rural income in Tanzania: An empirical approach. Research report 10/4, Research on Poverty Alleviation (REPOA).

[12] Norsida Man \& Sami Ismail Sadiya. 2006. Off-Farm Employment Participation Among Paddy Farmers In The Muda Agricultural Development Authority And Kemasin Semerak Granary Areas Of Malaysia. Asia-Pacific Development Journal 16(2): 141-153.

[13] Hair, J.F., W.C., Babin, B.J., Anderson, R.E. \& Tatham, R.L. 2006. Multivariate Data Analysis. Sixth Edition. New Jersey: Pearson Prentice Hall.

[14] Gujarati. M. 2003. Basic econonmetrics fourth edition. New York: McGraw-Hill Higher Education

[15] Griffiths,W.E, Hill, R.C., \& Judge,G.G.1993. Dummy variables in models with a log-transformed dependent variable. http://shazam.econ.ubc.ca/intro/dumlog.htm [20 Disember 2011].

Table 1 Distribution of average income per month paddy farmers

\begin{tabular}{lrr}
\hline Income sources & RM & Percent \\
\hline Agricultural income & 1375.57 & 63.60 \\
- Paddy rice subsidy & 221.71 & 10.25 \\
& & \\
Side income & 199.62 & 9.23 \\
- Rubber planting & 163.90 & 7.58 \\
- Livestock & 19.80 & 0.91 \\
- Fish farming in cages / ponds & 15.92 & 0.74 \\
& & \\
Non-agricultural income & 269.62 & 12.47
\end{tabular}


(Salary, wages, business, etc.)

Other income

- The contribution of children

- Rental income

$96.19 \quad 4.45$

- Pensions

- Zakat

- Assistance from government

- Others: dividends and interest

$38.67 \quad 1.79$

Total

$2162.71 \quad 100.00$

Table 2 Distribution of income of paddy farmers in the Muda

\begin{tabular}{llll}
\hline Category & Income range & Number & Percent \\
& & & \\
\hline Hardcore poor & < RM440 & - & - \\
Poor & RM441-RM750 & 8 & 3.56 \\
Non-poor & RM751-RM1000 & 24 & 10.67 \\
& RM1001-RM2000 & 110 & 48.9 \\
& RM2001-RM3000 & 40 & 17.8 \\
& RM3001-RM5000 & 33 & 14.7 \\
& $>$ RM5001 & 10 & 4.4 \\
Total & & 225 & 100 \\
\hline
\end{tabular}

Table 3 Empirical results on the determinants of income paddy farmers

\begin{tabular}{|c|c|c|c|c|}
\hline Variable & Coefficients & t-value & Dummy changes $(\%)$ & VIF \\
\hline $\begin{array}{l}\ln X_{1} \text {-own land (hectare) } \\
\ln X_{2} \text {-land rent (hectare) } \\
\ln X_{3} \text {-non farm income (percent) } \\
\ln X_{4} \text {-other income (percent) } \\
D_{1} \text {-dummy subsidy receipts }\end{array}$ & $\begin{array}{l}0.265 \\
0.129 \\
0.114 \\
0.016 \\
0.221\end{array}$ & $\begin{array}{l}3.517 * * * \\
1.778^{*} \\
1.907 * \\
0.285 \\
3.848^{* * *}\end{array}$ & 24.3 & $\begin{array}{l}1.813 \\
1.683 \\
1.145 \\
1.028 \\
1.052\end{array}$ \\
\hline $\begin{array}{l}\mathrm{D}_{2} \text {-dummy level education } \\
\mathrm{D}_{3} \text {-dummy health status } \\
\mathrm{D}_{4} \text {-dummy saving } \\
\mathrm{D}_{5} \text {-dummy sideline } \\
\mathrm{D}_{6} \text {-dummy household members working } \\
\text { Constant }\end{array}$ & $\begin{array}{l}0.103 \\
0.046 \\
0.004 \\
0.138 \\
0.235 \\
6.872 \\
\end{array}$ & $\begin{array}{l}1.802 * \\
0.792 \\
0.071 \\
2.293 * * \\
4.009 * * * \\
77.384 * * * \\
\end{array}$ & $\begin{array}{l}10.6 \\
10.6 \\
0.17 \\
14.3 \\
25.6\end{array}$ & $\begin{array}{l}1.041 \\
1.066 \\
1.177 \\
1.157 \\
1.094\end{array}$ \\
\hline $\begin{array}{l}\mathrm{R} \\
\bar{R}^{2} \\
\text { Standard Error } \\
\text { F-value }\end{array}$ & $\begin{array}{l}0.329 \\
0.298 \\
0.447 \\
10.505\end{array}$ & & & \\
\hline
\end{tabular}

*** significant at the level 99 percent

** $\quad$ significant at the level 95 percent

* $\quad$ significant at the level 90 percent 